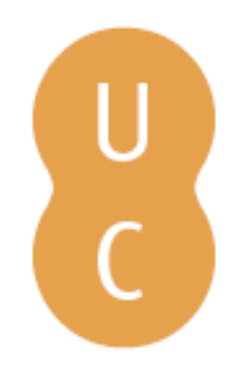

\title{
pompalina
}

\section{Evaluation of bloodstain detection tests for forensic applications}

Autor(es): $\quad$ Souto, L.; Moreira, $\mathrm{H}$.

Publicado por: Imprensa da Universidade de Coimbra; International Academy of Legal

URL

persistente: URI:http://hdl.handle.net/10316.2/31726

DOI: $\quad$ DOI:http://dx.doi.org/10.14195/978-989-26-0173-1_10

Accessed : $\quad$ 26-Apr-2023 12:04:54

A navegação consulta e descarregamento dos títulos inseridos nas Bibliotecas Digitais UC Digitalis, UC Pombalina e UC Impactum, pressupõem a aceitação plena e sem reservas dos Termos e Condições de Uso destas Bibliotecas Digitais, disponíveis em https://digitalis.uc.pt/pt-pt/termos.

Conforme exposto nos referidos Termos e Condições de Uso, o descarregamento de títulos de acesso restrito requer uma licença válida de autorização devendo o utilizador aceder ao(s) documento(s) a partir de um endereço de IP da instituição detentora da supramencionada licença.

Ao utilizador é apenas permitido o descarregamento para uso pessoal, pelo que o emprego do(s) título(s) descarregado(s) para outro fim, designadamente comercial, carece de autorização do respetivo autor ou editor da obra.

Na medida em que todas as obras da UC Digitalis se encontram protegidas pelo Código do Direito de Autor e Direitos Conexos e demais legislação aplicável, toda a cópia, parcial ou total, deste documento, nos casos em que é legalmente admitida, deverá conter ou fazer-se acompanhar por este aviso.

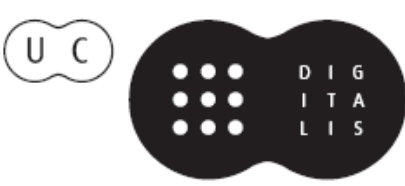




\section{Duarte Nuno Vieira Anthony Busuttil \\ Denis Cusack • Philip Beth}
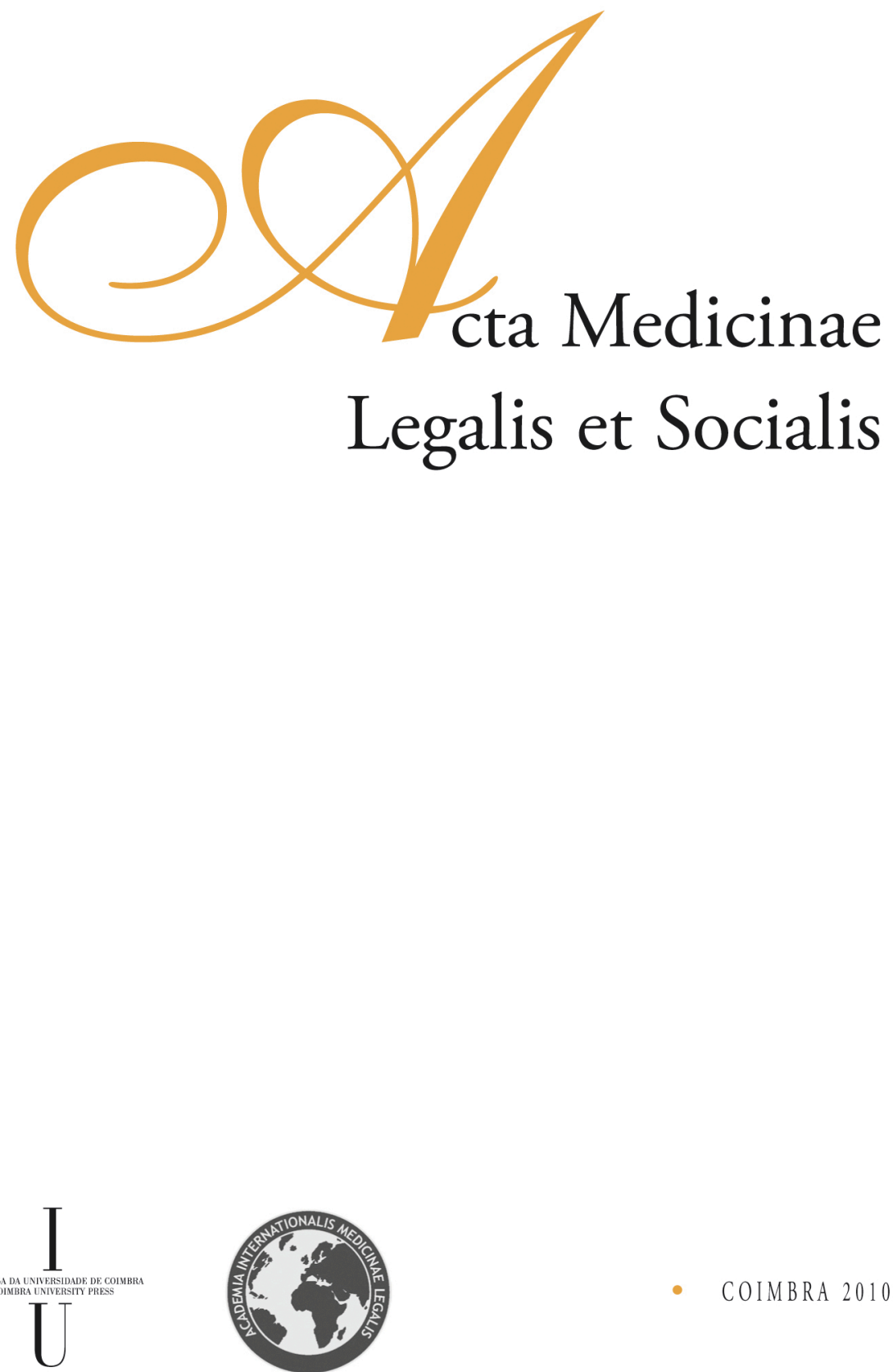
L. Souto ${ }^{1}$, H. Moreira ${ }^{1}$

${ }^{1}$ Department of Biology, University of Aveiro, Portugal

\title{
EVALUATION OF BLOODSTAIN DETECTION TESTS FOR FORENSIC APPLICATIONS
}

\begin{abstract}
Recently the Bluestar Forensic Kit $\AA$ a new luminol reagent based test was designed for blood detection. The aim of this study was to determine the followings parameters: time since collection; dilution and substrate. Samples of human and animal blood origin were tested according to those criteria. We verified that the Bluestar ${ }^{\circledR}$ Forensic Kit allows the detection of non-diluted and diluted bloodstains in different substrates. The maximum bloodstain dilution detected was 1/30 000 in denim jeans. False positive results due to the Bluestar ${ }^{\circledR}$ reaction with iron metallic particles present in everyday materials were frequent. The use of Bluestar ${ }^{\circledR}$ Forensic Kit on the samples does not interfere with DNA profile analysis. A non-diluted bloodstain was still detected although with less intensity, one month after reagent preparation. Two immunochromatographic tests (Rapid Stain Identification-RSID ${ }^{\circledR}$ and Hexagon $O B T I$ ) for confirmation of human blood were also compared. This study demonstrates that both are efficient but the Hexagon OBTI much quicker and essential to confirm the presence of human blood traces.
\end{abstract}

\section{Introduction}

Bloodstains may be present at crime scenes and can be found diluted as an attempt to conceal or hide evidence, by cleaning up blood-contaminated areas. These bloodstains can present different patterns on the floor and wall splashes. DNA analysis can determine the genetic profile of the crime perpetrator. We tested the Bluestar ${ }^{\circledR}$ Forensic Kit efficiency in different human and animal bloodstains. The Bluestar ${ }^{\circledR}$ Forensic Kit detects the presence of blood. This test contains two main chemicals, luminol and hydrogen peroxide, which react with the iron of blood cells producing a strong chemiluminescence blue light [1]. Two immunochromatographic tests - Rapid Stain Identification (RSID®) and Hexagon OBTI - were used as confirmatory tests for human blood origin. The RSID ${ }^{\circledR}$ test is based by the detection of glycophorin A present in red blood cells membrane, whereas the Hexagon OBTI detects human hemoglobin $(\mathrm{hHb})[1,2]$. 


\section{Materials and Methods}

The effect of the luminol based reagent over DNA extraction and amplification was evaluated as well reagent performance over time. In this study whole blood contained in $\mathrm{K} 3 \mathrm{E} / \mathrm{EDTA} 3 \mathrm{~K}$ tube was used to obtain several stains from different periods of time. Diluted bloodstains were also prepared and placed in various materials.

Samples of human and animal (duck, rabbit, pig, sheep, wild boar, fallow deer and otter) blood origin were tested for different criteria: time since collection (from 1 week old to 9 years); dilution - 1/2 to $1 / 100000$ and substrate (denim jeans, plants, aluminum, porcelain tiles, soil and metal supports). Some of the jean stains were submitted to a $5 \%$ bleach treatment followed by normal machine wash, $40^{\circ} \mathrm{C}$ plus commercial laundry detergent (Skip - composed of 15\% - 30\% zeolites, $5-15 \%$ bleaching agents based on oxygen, non-ionic surfactants, anionic surfactants; $<5 \%$ soap, polycarboxylates, phosphonates, perfume, brighteners, enzymes, citronellol Unilever). Negative controls (distilled milli-Q water) were also used.

The samples were submitted to a presumptive Luminol test using the Bluestar ${ }^{\circledR}$ Forensic Kit - Bluestar ${ }^{\circledR}$ to detect the presence of blood. In order to identify human blood origin samples, Immunochromatographic tests (Rapid Stain Identification-RSID® from Galantos Genetics GMBH and Hexagon OBTI from Bluestar $\left.{ }^{\circledR}\right)$ were used. Bloodstains in denim jeans that tested positive with both Bluestar ${ }^{\circledR}$ and Immunochromatographic tests were submitted to DNA extraction, accordingly to the Chelex® 100 [3] and Phenol-Chloroform [4] protocols. The Qubit ${ }^{\mathrm{TM}}$ Fluorometer - Invitrogen was used for DNA quantification and the PowerPlex® Y System Kit - Promega for PCR amplification. The DNA profile detection was performed in the ABI PRISM® 310 Genetic Analyzer - Applied Biosystems.

\section{Results}

\section{Substrates}

After Bluestar ${ }^{\circledR}$ application in different substrates - plant, denim jeans, aluminum, porcelain tiles, soil and metal supports - non-diluted bloodstains were detected with low natural light conditions.

\section{Dilutions}

Diluted bloodstains ranging from 1/250 - 1/30 000 from animals and human were only visible after the application of the Bluestar ${ }^{\circledR}$ producing an intense blue chemiluminescence light. However, dilutions 1/750 - 1/30 000 were only detected in dark conditions.

Since the Bluestar ${ }^{\circledR}$ Forensic Kit is unable to distinguish human from animal blood, immunochromatographic tests - Hexagon OBTI and the Rapid Stain Identification (RSID®) had to be used. These two tests present similar results the only difference was the response time period. We were able to obtain results in 10 minutes with the Hexagon OBTI, whereas the Rapid Stain Identification takes approximately 2 hours to get the viable results (Figures 1a, 1b). 


\section{DNA profiles}

Considering the positive results obtained through the immunochromatographic tests, DNA typing was performed on samples under the same conditions (volume, blood concentration and bloodstain period of time). The only difference was that some had been sprayed with the Bluestar ${ }^{\circledR}$ and others were not. The DNA typing revealed similar profiles with coincident genotypes (Figures $2 \mathrm{a}, 2 \mathrm{~b}$ ).

\section{Discussion}

The Bluestar ${ }^{\circledR}$ Forensic Kit is able to detect human and animal non-diluted and diluted bloodstains in different substrates - denim jeans, porcelain tiles, aluminum, soil, metal supports and plants. The presence of bloodstain was still detected with the luminol based reagent in denim jeans bloodstain treated with bleach and followed by machine wash. Bloodstains ranging from 1/250 - 1/30 000 dilutions in denim jeans were only visible after the application of the Bluestar ${ }^{\circledR}$ reagent. The highest dilution detected by Bluestar ${ }^{\circledR}$ was $1 / 30$ 000. Furthermore, on the contrary of manufacturer instructions, our results emphasize the need of total darkness when detecting high diluted bloodstains (1/750 up to $1 / 30000)$.

We observed strong cross reaction when applying Bluestar ${ }^{\circledR}$ over a variety of metal items. Due to the ubiquitous presence of iron metallic particles on ordinary materials, the possibility of false positive results must be taken in particularly consideration.

Despite the recommendation of using the reagent in 24 hours after preparation, we verified that a normal bloodstain was still detected one month later, although with less intensity. DNA typing revealed identical profiles in the samples treated and untreated with Bluestar ${ }^{\circledR}$. Therefore we can infer that the Bluestan ${ }^{\circledR}$ does not interfere with DNA analysis.

As expected the Bluestar ${ }^{\circledR}$ Forensic Kit was unable to distinguish human from animal blood. Two immunochromatographic tests - Hexagon OBTI and the Rapid Stain Identification (RSID®) - were used. These tests gave also no cross-reactivity with animal samples (duck, rabbit, pig, sheep, wild boar, fallow deer and otter) and present similar results. On the other hand the Hexagon OBTI does not require consuming of the questioned bloodstain and is completed in less time (10 minutes against 2 hours of the Rapid Stain Identification).

\section{Conclusions}

The Bluestar ${ }^{\circledR}$ Forensic Kit allows the detections of non-diluted and diluted bloodstains (up to 1/30 000) in different substrates. False positive results must be taken into account due to Bluestar ${ }^{\circledR}$ reaction with iron metallic particles present in everyday materials. We confirmed that the luminol based reagent does not interfere with DNA profiling. The use of Hexagon OBTI for confirmation of human blood is advisable as it is efficient, does not waste sample and it is not time consuming. 


\section{References}

[1] L. J. BLUM, PHILIPPE ESPERANÇA, STÉPHANIE ROCQUEFELTE, A New HighPerformance Reagent and Procedure for Latent Bloodstain Detection Based on Luminol Chemiluminescence, Canadian Society of Forensic Science Journal, 39(3), pp.81-100, 2006.

[2] GALANTOS GENETICS GMBH \& INDEPENDENT FORENSICS, Rapid Stain Identification of Human Blood (RSID ®-Blood), Blood, Pro Rev. B, 2006.

[3] WALSH, P.S., METZGER, D. A., HIGUCHI, R., Chelex 100 as a medium for simple extraction of DNA for PCR-based typing from forensic material, Biotechniques, 10(4), pp.506-513, 1991.

[4] SAMBROOK, J. \& RUSSEL D. W., Molecular Cloning, A Laboratory Manual, third ed., Cold Spring Harbor Laboratory Press, Cold Spring Harbor, New York, Appendix A8.20, 2001.

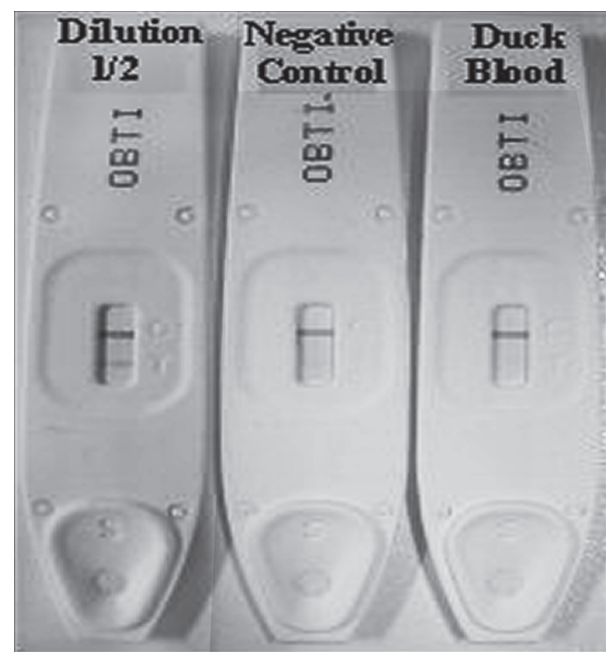

Figure 1a - Hexagon OBTI

immunochromatographic test (Dilution $1 / 2$ of human blood, Negative control and Duck blood - non human blood control).

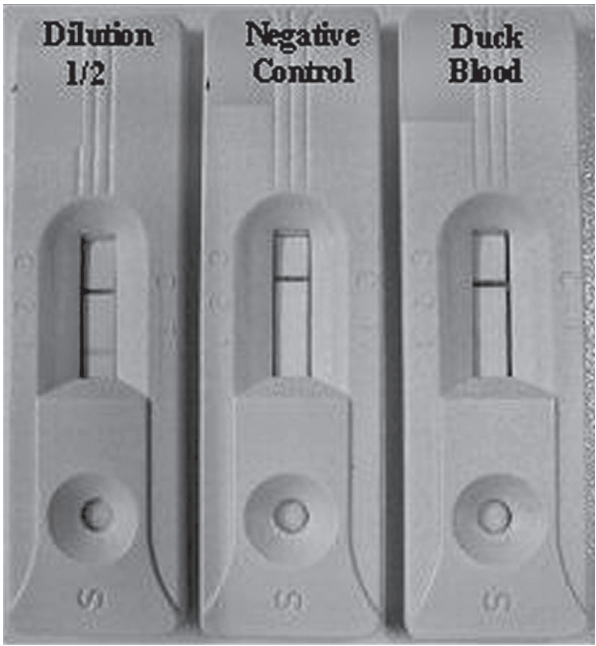

Figure $1 \mathrm{~b}$ - Rapid Stain Identification (RSID $\left.{ }^{\circledR}\right)$ immunochromatographic test (Dilution $1 / 2$ of human blood, Negative control and Duck blood - non human blood control). 


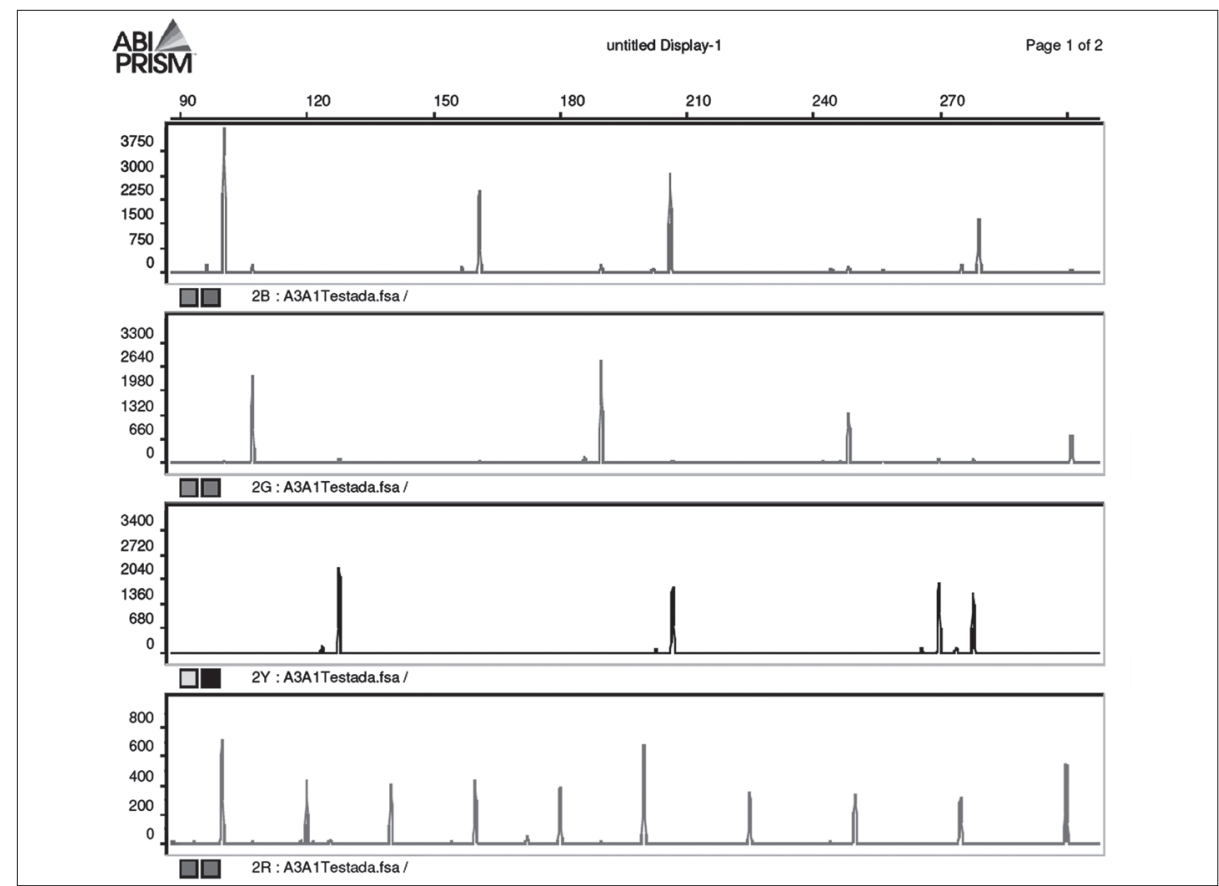

Figure 2a - DNA profile obtained from 1 month old bloodstain with Bluestar ${ }^{\circledR}$ reagent application.

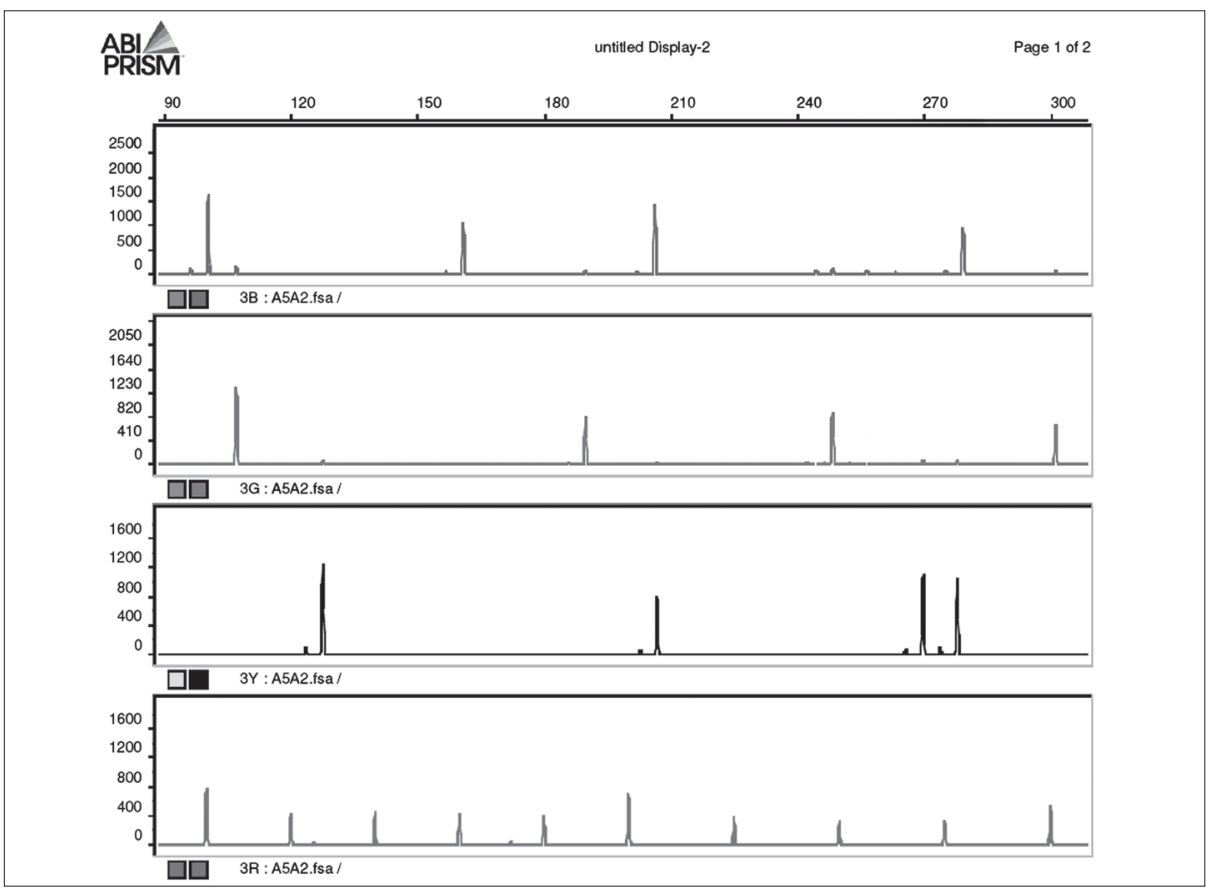

Figure $2 \mathrm{~b}$ - DNA profile obtained from 1 month old bloodstain without Bluestar ${ }^{\circledR}$ reagent application. 